The purpose of the congress will be to review the progress made in research in relation to architecture, building and the associated branches of civil engineering, and a large number of topics will be discussed. The programme will be organised in three divisions, which will hold concurrent meetings; visits to buildings of interest and to civil engineering works, etc., will also be arranged. Further details can be obtained from the Organising Secretary, Building Research Congress 1951, Building Research Station, Bucknalls Lane, Garston, Watford, Herts.

\section{Fresnel Diffraction Pattern and the Electron Microscope}

Mr. M. E. HAINE, of the Associated Electrical Industries Research Laboratory, Aldermaston, writes that his attention has recently been directed to the report on the "Conference on Electron Microscopy, Delft", published in Nature of September 17, 1949, p. 481. In the first column on p. $482 \mathrm{Mr}$. Haine is reported as suggesting the use of the Fresnel diffraction pattern from a half plane as a test object for the determination of resolution in the electron microscope. He wishes to say that, in fact, he went to some pains in his paper to point out the fallacy in such a test. In his suggestion for the use of a half plane as a test object, Mr. Haine declared that it is only suitable for conditions of incoherent illumination, and went on to explain the complications arising when any degree of coherence is introduced.

\section{The Night Sky in September}

NEw moon occurs on September 12d. 03h. $29 \mathrm{~m}$. U.T., and full moon on Sept. 26d. 04h. $21 \mathrm{~m}$. The following conjunctions with the moon take place: Sept. 10d. 20h., Venus $1^{\circ}$ S. ; Sept. 16d. 17h., Mars $3^{\circ} \mathrm{N}$. ; Sept. 23d. 13h., Jupiter $1^{\circ}$ N. In addition to these conjunctions with the moon, the following other conjunctions occur : Sept. 9d. 04h., Venus with Regulus, Venus $0.7^{\circ}$ N.; Sept. 24d. 03h., Mercury with Venus, Mercury $2 \cdot 6^{\circ}$ S. ; and Sept. 29d. 22h., Venus with Saturn, Venus $0 \cdot 6^{\circ} \mathrm{S}$. Mercury is an evening star during the earlier part of the month, setting at $19 \mathrm{~h}$. on Sept. 1, but is too close to the sun to be observed. On Sept. 17 the planet is in inferior conjunction and at the end of the month rises $1 \frac{1}{2}$ hours before the sun. Venus is a morning star, the times of rising being $3 \mathrm{~h} .25 \mathrm{~m} ., 4 \mathrm{~h} .05 \mathrm{~m}$. and 4h. $55 \mathrm{~m}$. on Sept. 1, 15 and 30, respectively, and can be seen in the morning hours, stellar magnitude $-3 \cdot 3$. Mars can be seen for a short period in the evening, setting at $20 \mathrm{~h}$. $35 \mathrm{~m} ., 20 \mathrm{~h}$. and $19 \mathrm{~h} .30 \mathrm{~m}$. at the beginning, middle and end of the month, respectively. Jupiter is visible throughout the night, setting in the morning hours at $4 \mathrm{~h} .30 \mathrm{~m}$. on Sept. 1 , and $2 \mathrm{~h} .20 \mathrm{~m}$. on Sept. 30. Saturn, in conjunction with the sun on Sept. 16, is not favourably placed for observation until the end of the month, when it is a morning star, rising more than an hour before sunrise, and can then be seen for a short time in the eastern sky. Occulta. tions of stars brighter than magnitude 6 are as follows: Sept. 30d. 20h. 31-1m., 27 Taur. $m .(D)$; Sept. 30d. 2lh. 26.3m., 27 Taur. $m .(R)$; Sept. 30d. $21 \mathrm{~h}$. $26 \cdot 7 \mathrm{~m} ., 28$ Taur. $(R)$. $R$ and $D$ refer to reappearance and disappearance, respectively, and the latitude of Greenwich is assumed. A total eclipse of the sun, invisible at Greenwich, occurs on Sept. 12. The central line runs from lat. $85^{\circ} 10^{\prime} \mathrm{N}$., long. $66^{\circ} 42^{\prime} \mathrm{E}$., to lat. $34^{\circ} 23 \mathrm{~N}$., long. $154^{\circ} 35^{\prime} \mathrm{E}$. The circumstances of the eclipse are :

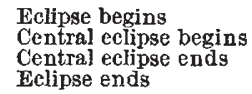

A total eclipse of the moon, partly visible at Greenwich, takes place on Sept. 26, the circumstances being:

$$
\begin{aligned}
& \text { Moon enters penumbra } \\
& \text { Total eclipse begins } \\
& \text { Middle of the eclipse } \\
& \text { Total eclipse ends } \\
& \text { Moon leaves umbra } \\
& \text {," , penumbra }
\end{aligned}
$$

$\begin{array}{cll}\text { Sept. } 26 \text { d. } & 01 \mathrm{~h} . & 20 \cdot 0 \mathrm{~m} \\ 26 & 02 & 31 \cdot 5 \\ 26 & 03 & 53 \cdot 8 \\ 26 & 04 & 16 \cdot 7 \\ 26 & 04 & 39 \cdot 6 \\ 26 & 06 & 01 \cdot 9 \\ 26 & 07 & 13 \cdot 5\end{array}$

Vernal equinox is on Sept. 23d. 15h.

\section{Announcements}

The College of Physicians of Philadelphie has awarded the Alvarenga Prize for 1950 to Dr. Ephraim Shorr, associate professor of medicine, Cornell University Medical College, for his outstanding work on the mechanism of shock. The Alvarenga Prize was established by the will of P. F. DaC. Alvarenga, of Lisbon, Portugal, an associate fellow of the College of Physicians of Philadelphia, to be awarded annually by the College on the anniversary of his death on July 14,1883 .

A CONFERENCE on differential anthropology has been organised by the Société de Morpho-physiologie humaine and will be held at the Abbaye de Royaumont (near Paris) during September 11-16. The programme of the conference will be devoted to the study of the morphological, physiological and psychological aspects of the differentiation of individuals, and a number of participants from countries other than France will be contributing papers. Further details can be obtained from the secretary-general of the conference, Dr. P. Mabille, 34 rue Raynouard, Paris 16 .

ThE Research Fund of the Chemical Society provides grants for the assistance of research in all branches of chemistry. About seven hundred pounds a year is available for this purpose, the income being derived from a donation of the Worshipful Company of Goldsmiths, from the Perkin Memorial Fund, and from other sources. Application forms, obtainable from the General Secretary, Chemical Society, Burlington House, Piccadilly, London, W.1, should be submitted not later than November 1. Applications from Fellows of the Society will receive prior consideration.

The premises of the headquarters of the British Scientific Instrument Research Association, 17 Princes Gate, London, S.W.7, have been acquired by the Government of Ethiopia for its Legation and must be vacated by the end of August. Consequently, it has been decided to move the information department and the library of the Association immediately to the Association's laboratories at 'Sira', Southill, Elmstead Woods, Chislehurst, Kent. Temporary accommodation will be provided in an existing bungalow within the grounds of the laboratories; but it is hoped that a new building, for which plans have already been approved, will be erected and completed by the summer of 1951. The bungalow will then form an annexe to the library and will provide valuable storage space for many years to come. New headquarters in London for the director and administrative staff are being sought. 